\title{
Development of fragility curve due to the effect of tsunami force on existing building in Banda Aceh city
}

\author{
$Z u \operatorname{Irfan}^{1, *}$, Abdullah ${ }^{2}$, Moch. Afifuddin ${ }^{2}$ \\ ${ }^{1} \mathrm{PhD}$ Candidate, Doctor of Engineering Study Program, Syiah Kuala University, Jl. Syech Abdurrauf, Banda Aceh, 23111, Indonesia \\ ${ }^{2}$ Civil Engineering Department, Syiah Kuala University, Jl. Syech Abdurrauf, Banda Aceh, 23111, Indonesia
}

\begin{abstract}
Aceh is located on the Indian Ocean Coast which is very prone to Tsunamis, this is due to frequent large earthquakes due to Megatrust faults, such as those that occurred during the earthquake on December 26, 2004. Based on the 2012 Aceh earthquake, the Acehnese prefer horizontal evacuation to vertical evacuation [1]. In this case, many people in Banda Aceh do not believe in the strength of TVE buildings (distrust building). From this research, it it is possible for the Acehnese will do the same thing in the future when the tsunami occurs. Horizontal evacuation puts them at risk of traffic accidents so that they cannot reach a safe area in a short time, whereas through vertical evacuation they can reach the TVE of a building in a short time due to its proximity to settlements. When the earthquake and tsunami occured Banda Aceh in 2004, many buildings were destroyed due to the earthquake load and also the Tsunami load. For this problem, a vulnerability analysis of buildings that can be used as TVE buildings can be carried out. If an earthquake magnitude more than $7.0 \mathrm{Mw}$ can cause a tsunami, the TVE building should be counted on the structural strength caused by the Tsunami waves. In this research, a hydrodynamic analysis will be carried out due to air pressure and collision which is a function of velocity and depth of flow and also the influence of drag and drift variables on the building.
\end{abstract}

\section{Introduction}

Aceh is located on the Indian Ocean Coast which is very vulnerable to Tsunami hazards, this is because large earthquakes often occur due to megatrust faults, such as what happened during the earthquake in 26 December 2004. Therefore, it is necessary to assess the vulnerability of the building to forces due to earthquake and tsunami loads. The Indian Ocean coast is very vulnerable to Tsunamis [2], and Sumatra Island is a seismic gap area which has the potential for large-scale earthquakes [3].

Y. Goto et al. found that during the earthquake that occurred on April 11, 2012, in Banda Aceh, although in 2012 it did not cause a Tsunami, $78 \%$ of refugees were stuck in traffic. Only about $22 \%$ of those evacuated from nearshore areas reached their destination within 20 minutes after the earthquake (this only increased to $43 \%$ at 40 minutes) [4]. The survey also found that vertical evacuation reduced evacuation time: $71 \%$ of those evacuated to a tall building or mosque reached this destination within 20 minutes (this rose to about $91 \%$ at 40 minutes), while only $\sim 15 \%$ of those who evacuated horizontally reach their destination within 20 minutes (this rises to only $35 \%$ at 40 minutes) [4].

Jamie W. McCaughey found that during the 2012 Aceh earthquake, many people preferred to carry out

From the study it was found that those who evacuated horizontally to inland destinations during the 2012 earthquake in Aceh province or intend to do in the

\footnotetext{
* Corresponding author: zuirfan.eng@gmail.com
}

horizontal evacuations rather than using vertical evacuation buildings that had been built such as escape buildings, this was because many people in Banda Aceh lacked confidence in the power of TVE buildings (distrust buildings) [1].

future think that escape buildings are unsafe and they think they can reach their inland destinations in time. However horizontal evacuation puts them at risk of traffic accidents, that they cannot reach safe inland destinations in a short time, but if they can reach escape buildings in a short time because they are close to settlements. The research also found several alternative designs that can increase the use of escape buildings, namely escape buildings are on a horizontal evacuation route to the interior (away from the coast), it is also mentioned that escape buildings that can substantially increase community intention to evacuate to escape buldings are, if it is a place of worship/mosque building.

Based on this research, many mosque buildings located on horizontal evacuation routes to the interior are also used as places of refuge, so that in the future mosques can be used as buildings that can function as buildings for Tsunami evacuation or later in this study called Tsunami Vertical Evacuation Buildings. TVE Buildings).

\section{Study area}

This study only focuses on assessing the condition of the existing building which is carried out by survey or direct assessment. Existing buildings are buildings that are in the utilization stage. This study examines existing 


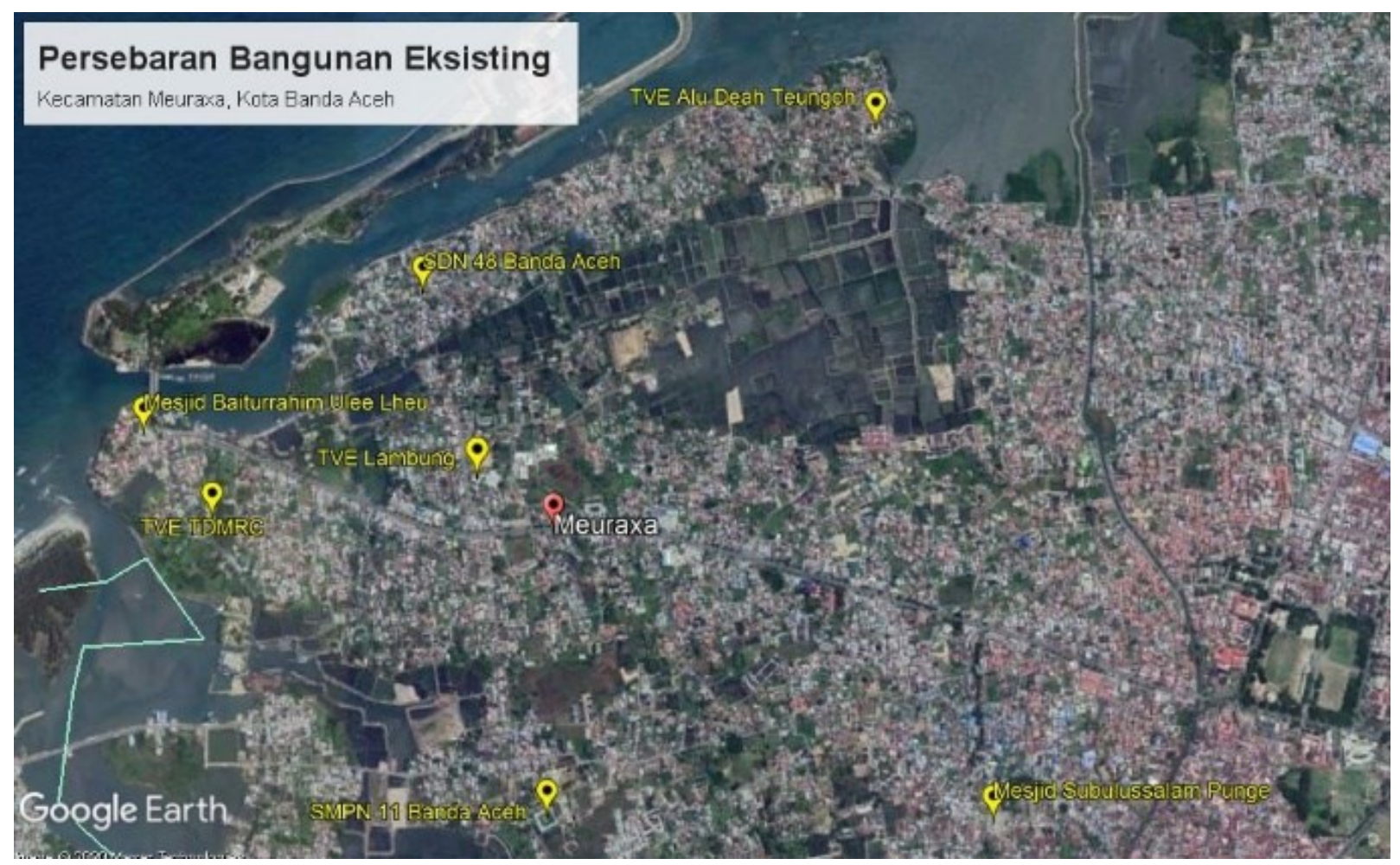

Fig. 1. Map of the distribution of existing buildings that are the object of research

buildings scattered in Meuraxa District, Banda Aceh City. Existing buildings that are the object of research in this study include the Tsunami Vertical Evacuation (TVE) of Lambung, TVE Alu Deah Teungoh, TVE TDMRC, SDN 48 Banda Aceh, SMPN 11 Banda Aceh, Baiturrahim Ulee Lheu Mosque, and Subulussalam Punge Mosque.

\section{Methodology}

\subsection{Tsunami loads}

The calculation of the tsunami loads is carried out by simulating buildings with tsunami flow heights as high as 2 meters, 4 meters, 6 meters, 7 meters, and 8 meters. This height is taken randomly so that it can show the drift ratio at each level. The equation used in calculating the tsunami load is using the standard from FEMA P646 [5]. The tsunami forces that are reviewed are hydrodynamic forces, impulsive forces, and floating debris impact forces.

Hydrodynamic forces are used when water flows around a building structure. so it can be concluded that this force was applied to all structures affected by the

tsunami. hydrodinamic forces can be computed using the following equation

$F_{h}=\frac{1}{2} \rho_{s} C_{d} B\left(h u^{2}\right)_{\max }$ where $\rho_{\mathrm{s}}$ is the fluid density including sediment (1100 $\mathrm{kg} / \mathrm{m}^{3}=2.13$ slugs $\left./ \mathrm{ft}^{3}\right), \mathrm{Cd}$ is the drag coefficient, $\mathrm{B}$ is the breadth of the structure in the plane normal to the direction of, $\mathrm{h}$ is flow depth, and $\mathrm{u}$ is flow velocity at the location of the structure. The drag coefficient may be conservatively taken as $\mathrm{Cd}=2.0$; the actual value is shape-, orientation-, and size-dependent.

The combination $\mathrm{hu}^{2}$ represents the momentum flux per unit mass per unit width. The value $\left(\mathrm{hu}^{2}\right) \max$ can be roughly estimated based on information in the inundation map, using

$\left(h u^{2}\right)_{\max }=g R^{2}\left(0,125-0,235 \frac{z}{R}+0,11\left(\frac{z}{R}\right)^{2}\right)$

where $\mathrm{g}$ is the acceleration due to gravity, $\mathrm{R}$ is the design runup elevation taken as 1.3 times the maximum runup elevation, $\mathrm{R}^{*}$, and $\mathrm{z}$ is the ground elevation at the base of the structure.

While the impulsive force will act on the component that is subjected to the front end of the tsunami wave which usually occurs in buildings that have been previously flooded which can be calculated by the equation:

$F_{s}=1,5 F_{d}$

At the time of the tsunami there was large debris that was carried away by the flow of water, resulting in a debris impact force on the structure of the building. The large debris impact force can cause damage to the building, so it needs to be calculated using the equation: 
$F_{i}=1,3 u_{\max } \sqrt{k m_{d}(1+c)}$

where 1.3 is the importance Coefficient for Risk Category IV structures that is specified by ASCE 7 Chapter 5 for debris impacts,

umax is the maximum flow velocity carrying the debris at the site, can be computed using:

$u_{\text {maks }}=\sqrt{\left(2 g R\left(1-\frac{z}{R}\right)\right)}$

and $c$ is a hydrodynamic mass coefficient which represents the effect of fluid in motion with the debris. In this study, lumber of wood log with the mass and the effective stiffness of the debris equal to $450 \mathrm{~kg}$ and $2.4 \cdot 10^{6} \mathrm{~N} / \mathrm{m}$ respectively is considered as the waterborne debris, this value approximately proposed by FEMA P646 [5].

These tsunami forces will be used in a combination of tsunami loading based on FEMA P646 using the equation:

$\mathrm{U}=1,2 \mathrm{D}+1,0 \mathrm{TS}+1,0 \mathrm{LREF}+0,25 \mathrm{~L}$
$\mathrm{U}=0,9 \mathrm{D}+1,0 \mathrm{TS}$

\subsection{Fragility curve}

The fragility curve describes the probability that it exceeds the specified level of damage in a tsunami event with a certain intensity [6]. In this study, the damage model based on HAZUS that defines four structural damage states according to the drift ratio based on Medina (2019)[7], can be seen in Table 1.

Table 1. Damage States Limits

\begin{tabular}{|l|l|}
\hline $\begin{array}{l}\text { Structural Damage } \\
\text { States }\end{array}$ & $\begin{array}{l}\text { Drift Damage Index } \\
\text { HAZUS - 1-3 stories }\end{array}$ \\
\hline Slight & $<0.20 \%$ \\
\hline Moderate & $0.20 \%-0.50 \%$ \\
\hline Extensive & $0.50 \%-1.20 \%$ \\
\hline Complete & $1.20 \%-2.80 \%$ \\
\hline
\end{tabular}

The results of nonlinear numerical analysis of inundation depth and drift ratio can be used to obtain a fragility curve which is expressed as a two-parameter lognormal distribution function. The following equation will give the cumulative probability of exceeding the damage level conditioned on the tsunami intensity measure.

$\mathrm{P}_{(\mathrm{DSi} \mid \mathrm{IM})}=\Phi\left(\frac{\ln (I M)-\ln \left(\overline{I M_{\mathrm{t}}}\right)}{\beta}\right)$

where is $\Phi$ a standard normal cumulative distribution function, IM is a measure of tsunami intensity expressed in inundation depth (in units of $\mathrm{m}$ ), IMi is the median value (in units of $\mathrm{m}$ ) for each level of damage and $\beta$ is the uncertainty calculated through the log standard deviation parameter in each level of damage. The value of uncertainty can be calculated using the equation. where, $\mathrm{c}$ is the uncertainty of the structural capacity which taken as 0.15 (based on the HAZUS MHTechnical Manual)[8] and D is the uncertainty of the structural demand which is considered by calculating the logarithmic dispersion at each level of damage. The results of the calculation of the standard deviation of the total uncertainty in each damage condition.

\section{Result and discussion}

The tsunami fragility curve requires the value of the inundation depth in meters (m) according to the limit state. The value of inundation depth at each damage limit for each height can be seen in Table 2-15

Table 2. TVE Lambung $x$ direction

\begin{tabular}{|l|c|c|c|}
\hline $\begin{array}{c}\text { Structural Damage } \\
\text { States }\end{array}$ & $\begin{array}{c}\mathbf{1}^{\text {st }} \\
\text { stories }\end{array}$ & $\begin{array}{c}\mathbf{2}^{\text {nd }} \\
\text { stories }\end{array}$ & $\begin{array}{c}\mathbf{3}^{\text {rd }} \\
\text { stories }\end{array}$ \\
\hline Slight $(<0,2 \%)$ & 18 & 22 & 22 \\
\hline Moderate (0,2\%-0,5\%) & 25 & 32 & 32 \\
\hline Extensive (0,5\%-1,2\%) & 33 & 42 & 42 \\
\hline Complete (1,2\%-2,8\%) & 42 & 54 & 54 \\
\hline
\end{tabular}

Table 3. TVE Lambung y direction

\begin{tabular}{|l|c|c|c|}
\hline $\begin{array}{c}\text { Structural Damage } \\
\text { States }\end{array}$ & $\begin{array}{c}\text { 1st } \\
\text { stories }\end{array}$ & $\begin{array}{c}\text { 2nd } \\
\text { stories }\end{array}$ & $\begin{array}{c}\text { 3rd } \\
\text { stories }\end{array}$ \\
\hline Slight $(<0,2 \%)$ & 0,2 & 6 & 14 \\
\hline Moderate $(0,2 \%-0,5 \%)$ & 0,5 & 11 & 26 \\
\hline Extensive $(0,5 \%-1,2 \%)$ & 1,2 & 17 & 40 \\
\hline Complete $(1,2 \%-2,8 \%)$ & 6,4 & 26 & 61 \\
\hline
\end{tabular}

Table 4. TVE Alu Deah Teungoh x direction

\begin{tabular}{|l|c|c|c|}
\hline $\begin{array}{c}\text { Structural Damage } \\
\text { States }\end{array}$ & $\begin{array}{c}\text { 1st } \\
\text { stories }\end{array}$ & $\begin{array}{c}\text { 2nd } \\
\text { stories }\end{array}$ & $\begin{array}{c}\text { 3rd } \\
\text { stories }\end{array}$ \\
\hline Slight $(<0,2 \%)$ & 20 & 24 & 24 \\
\hline Moderate $(0,2 \%-0,5 \%)$ & 29 & 35 & 35 \\
\hline Extensive (0,5\%-1,2\%) & 37 & 46 & 46 \\
\hline Complete (1,2\%-2,8\%) & 47 & 60 & 60 \\
\hline
\end{tabular}

Table 5. TVE Alu Deah Teungoh y direction

\begin{tabular}{|l|c|c|c|}
\hline $\begin{array}{c}\text { Structural Damage } \\
\text { States }\end{array}$ & $\begin{array}{c}\text { 1st } \\
\text { stories }\end{array}$ & $\begin{array}{c}\text { 2nd } \\
\text { stories }\end{array}$ & $\begin{array}{c}\text { 3rd } \\
\text { stories }\end{array}$ \\
\hline Slight $(<0,2 \%)$ & 0,1 & 3,5 & 5 \\
\hline Moderate $(0,2 \%-0,5 \%)$ & 1,3 & 6,5 & 12 \\
\hline Extensive (0,5\%-1,2\%) & 5,5 & 11 & 20 \\
\hline Complete (1,2\%-2,8\%) & 11,2 & 31 & 31 \\
\hline
\end{tabular}

Table 6. TVE TDMRC $\mathrm{x}$ direction

\begin{tabular}{|c|c|c|c|}
\hline $\begin{array}{c}\text { Structural Damage } \\
\text { States }\end{array}$ & $\begin{array}{c}\text { 1st } \\
\text { stories }\end{array}$ & $\begin{array}{c}\text { 2nd } \\
\text { stories }\end{array}$ & $\begin{array}{c}\text { 3rd } \\
\text { stories }\end{array}$ \\
\hline Slight $(<0,2 \%)$ & 3,1 & 7,2 & 14 \\
\hline Moderate $(0,2 \%-0,5 \%)$ & 5,1 & 14,5 & 19,5 \\
\hline Extensive (0,5\%-1,2\%) & 9,8 & 23 & 23,5 \\
\hline Complete (1,2\%-2,8\%) & 16 & 35,5 & 29 \\
\hline
\end{tabular}


Table 7. TVE TDMRC y direction

\begin{tabular}{|l|c|c|c|}
\hline $\begin{array}{c}\text { Structural Damage } \\
\text { State }\end{array}$ & $\begin{array}{c}\text { 1st } \\
\text { stories }\end{array}$ & $\begin{array}{c}\text { 2nd } \\
\text { stories }\end{array}$ & $\begin{array}{c}\text { 3rd } \\
\text { stories }\end{array}$ \\
\hline Slight $(<0,2 \%)$ & 0,4 & 3,0 & 4,9 \\
\hline Moderate $(0,2 \%-0,5 \%)$ & 1,45 & 4,8 & 7,9 \\
\hline Extensive (0,5\%-1,2\%) & 2,65 & 5,9 & 12 \\
\hline Complete (1,2\%-2,8\%) & 4,61 & 8,46 & 17,8 \\
\hline
\end{tabular}

Table 8. SDN 48 Banda Aceh $x$ direction

\begin{tabular}{|l|c|c|}
\hline \multicolumn{1}{|c|}{$\begin{array}{c}\text { Structural Damage } \\
\text { States }\end{array}$} & $\begin{array}{c}\text { 1st } \\
\text { stories }\end{array}$ & $\begin{array}{c}\text { 2nd } \\
\text { stories }\end{array}$ \\
\hline Slight $(<0,2 \%)$ & 2 & 8 \\
\hline Moderate $(0,2 \%-0,5 \%)$ & 7 & 12,5 \\
\hline Extensive $(0,5 \%-1,2 \%)$ & 14 & 16,5 \\
\hline Complete $(1,2 \%-2,8 \%)$ & 24 & 21,2 \\
\hline
\end{tabular}

Table 9. SDN 48 Banda Aceh y direction

\begin{tabular}{|l|c|c|}
\hline \multicolumn{1}{|c|}{$\begin{array}{c}\text { Structural Damage } \\
\text { States }\end{array}$} & $\begin{array}{c}\text { 1st } \\
\text { stories }\end{array}$ & $\begin{array}{c}\text { 2nd } \\
\text { stories }\end{array}$ \\
\hline Slight $(<0,2 \%)$ & 0,1 & 1 \\
\hline Moderate $(0,2 \%-0,5 \%)$ & 0,2 & 2 \\
\hline Extensive $(0,5 \%-1,2 \%)$ & 0,5 & 3 \\
\hline Complete $(1,2 \%-2,8 \%)$ & 1 & 5 \\
\hline
\end{tabular}

Table 10. SMPN 11 Banda Aceh $\mathrm{x}$ direction

\begin{tabular}{|l|l|l|}
\hline \multicolumn{1}{|c|}{$\begin{array}{c}\text { Structural Damage } \\
\text { States }\end{array}$} & $\begin{array}{c}\text { 1st } \\
\text { stories }\end{array}$ & $\begin{array}{c}\text { 2nd } \\
\text { stories }\end{array}$ \\
\hline Slight $(<0,2 \%)$ & 12 & 14 \\
\hline Moderate $(0,2 \%-0,5 \%)$ & 20 & 20 \\
\hline Extensive $(0,5 \%-1,2 \%)$ & 25 & 26 \\
\hline Complete $(1,2 \%-2,8 \%)$ & 32 & 33 \\
\hline
\end{tabular}

Table 11. SMPN 11 Banda Aceh y direction

\begin{tabular}{|l|c|c|}
\hline $\begin{array}{c}\text { Structural Damage } \\
\text { States }\end{array}$ & $\begin{array}{c}\text { 1st } \\
\text { stories }\end{array}$ & $\begin{array}{c}\text { 2nd } \\
\text { stories }\end{array}$ \\
\hline Slight $(<0,2 \%)$ & 0,05 & 0,1 \\
\hline Moderate $(0,2 \%-0,5 \%)$ & 0,1 & 0,3 \\
\hline Extensive $(0,5 \%-1,2 \%)$ & 0,3 & 1 \\
\hline Complete $(1,2 \%-2,8 \%)$ & 1 & 2,1 \\
\hline
\end{tabular}

Table 12. Mesjid Baiturrahim Ulee Lheu $x$ direction

\begin{tabular}{|l|c|c|}
\hline \multicolumn{1}{|c|}{$\begin{array}{c}\text { Structural Damage } \\
\text { States }\end{array}$} & $\begin{array}{c}\text { 1st } \\
\text { stories }\end{array}$ & $\begin{array}{c}\text { 2nd } \\
\text { stories }\end{array}$ \\
\hline Slight $(<0,2 \%)$ & 0,01 & 0,02 \\
\hline Moderate $(0,2 \%-0,5 \%)$ & 0,17 & 0,2 \\
\hline Extensive $(0,5 \%-1,2 \%)$ & 0,39 & 0,4 \\
\hline Complete $(1,2 \%-2,8 \%)$ & 0,95 & 0,95 \\
\hline
\end{tabular}

Table 13 Mesjid Baiturrahim Ulee Lheu y direction

\begin{tabular}{|c|c|c|}
\hline $\begin{array}{c}\text { Structural Damage } \\
\text { States }\end{array}$ & $\begin{array}{c}\text { 1st } \\
\text { stories }\end{array}$ & $\begin{array}{c}\text { 2nd } \\
\text { stories }\end{array}$ \\
\hline Slight $(<0,2 \%)$ & 22 & 23 \\
\hline Moderate $(0,2 \%-0,5 \%)$ & 33 & 35 \\
\hline Extensive $(0,5 \%-1,2 \%)$ & 43,9 & 45 \\
\hline Complete $(1,2 \%-2,8 \%)$ & 56,2 & 58,5 \\
\hline
\end{tabular}

Table 14. Mesjid Subulussalam Punge x direction

\begin{tabular}{|l|c|c|c|}
\hline $\begin{array}{c}\text { Structural Damage } \\
\text { States }\end{array}$ & Base & $\begin{array}{c}\text { 1st } \\
\text { stories }\end{array}$ & $\begin{array}{c}\text { 2nd } \\
\text { stories }\end{array}$ \\
\hline Slight $(<0,2 \%)$ & 5 & 10 & 16 \\
\hline Moderate $(0,2 \%-0,5 \%)$ & 12,5 & 24 & 34 \\
\hline Extensive $(0,5 \%-1,2 \%)$ & 22 & 39 & 54 \\
\hline Complete $(1,2 \%-2,8 \%)$ & 35,5 & 62 & 84 \\
\hline
\end{tabular}

Table 15. Mesjid Subulussalam Punge y direction

\begin{tabular}{|l|c|c|c|}
\hline $\begin{array}{c}\text { Structural Damage } \\
\text { States }\end{array}$ & Base & $\begin{array}{c}\text { 1st } \\
\text { stories }\end{array}$ & $\begin{array}{c}\text { 2nd } \\
\text { stories }\end{array}$ \\
\hline Slight $(<0,2 \%)$ & 0,05 & 0,1 & 8 \\
\hline Moderate $(0,2 \%-0,5 \%)$ & 0,3 & 0,6 & 17 \\
\hline Extensive $(0,5 \%-1,2 \%)$ & 0,73 & 1,3 & 29 \\
\hline Complete $(1,2 \%-2,8 \%)$ & 1,65 & 3,18 & 46 \\
\hline
\end{tabular}

Based on the displacement results for each tsunami height, it can be seen that the structure responds differently to each tsunami inundation that is used as a load. However, generally they have the same tendency, displacement in the $\mathrm{y}$-direction is larger than the $\mathrm{x}$ direction. But, it depends on the condition of the building's location towards tsunami.

The probability value on the fragility curve is plotted on the $y$-axis (ordinate) and the inundation depth on the $x$ axis (absis). so that the results of the brittle curve are obtained at various damage limits, it can be seen in Fig 2-15.

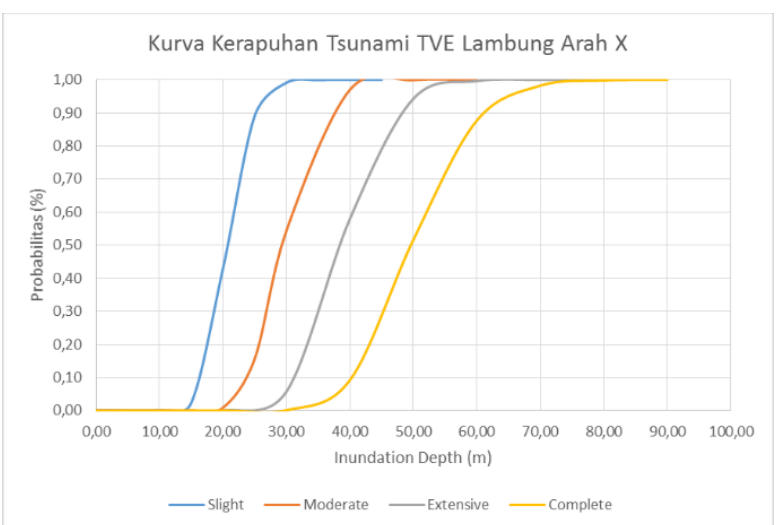

Fig. 2. Fragility Curve of TVE Lambung x-direction

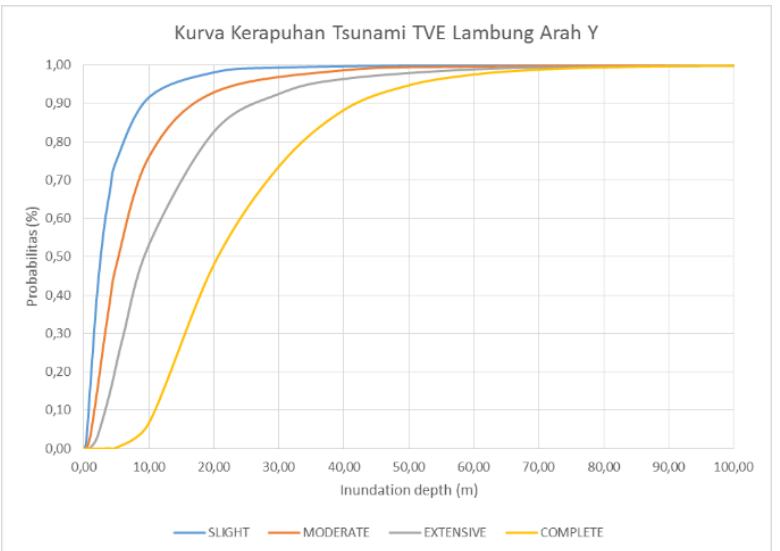

Fig. 3. Fragility Curve of TVE Lambung y-direction 


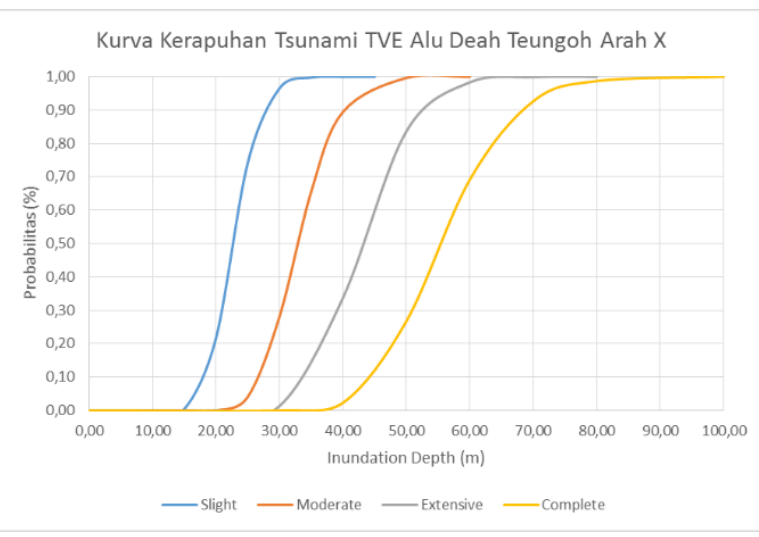

Fig. 4. Fragility Curve of TVE Alu Deah Teungoh x-direction

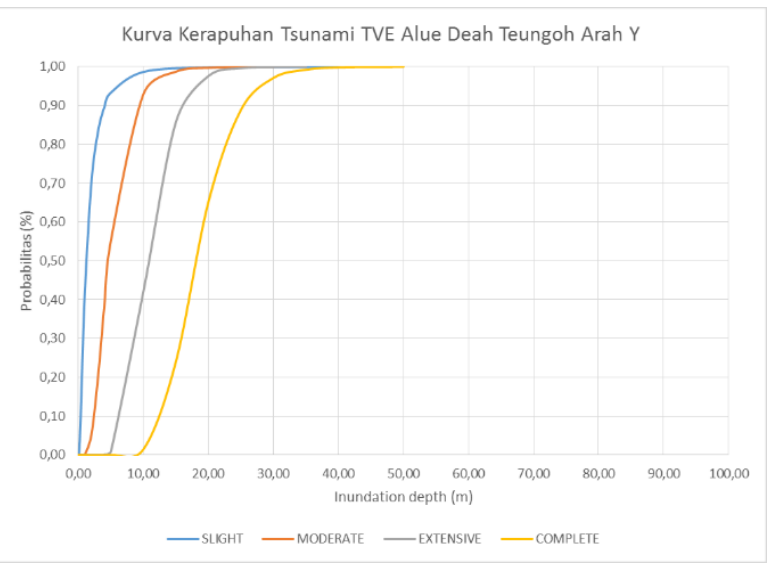

Fig. 5. Fragility Curve of TVE Alu Deah Teungoh y-direction

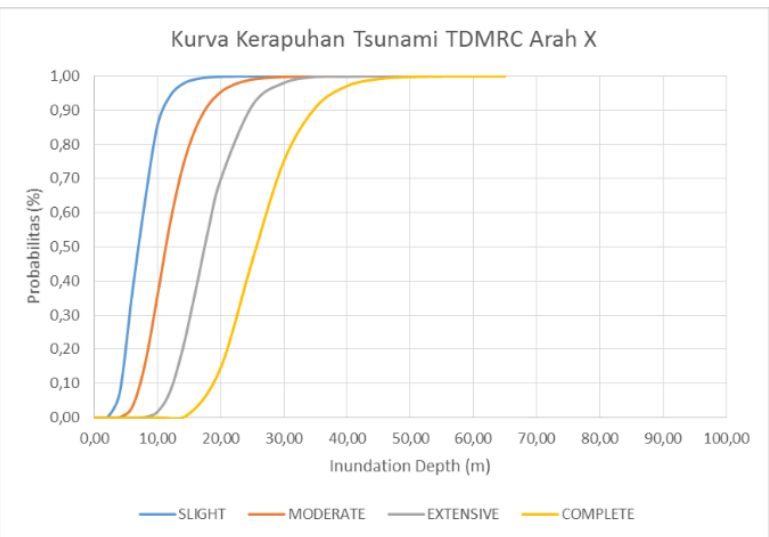

Fig. 6. Fragility Curve of TVE TDMRC x-direction

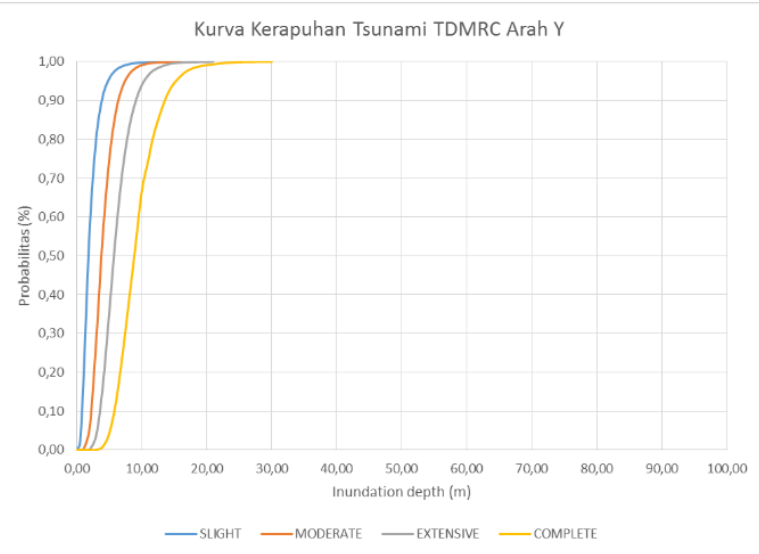

Fig. 7. Fragility Curve of TVE TDMRC y-direction

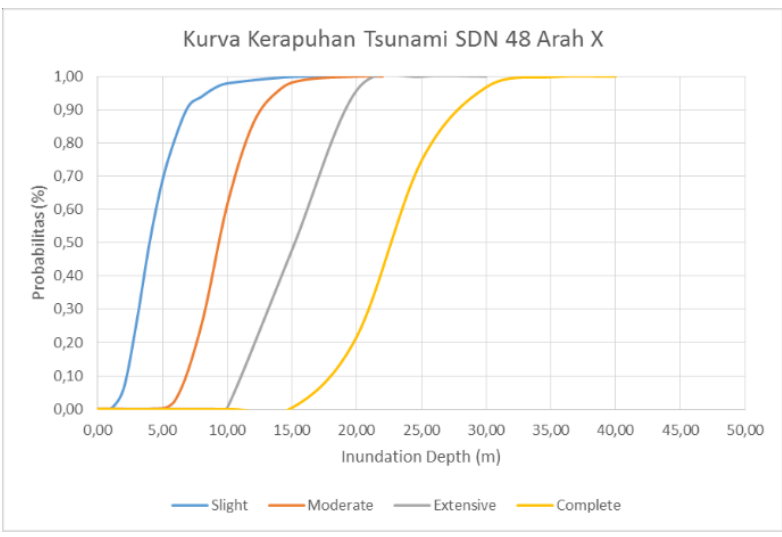

Fig. 8. Fragility Curve of SDN 48 Banda Aceh x-direction

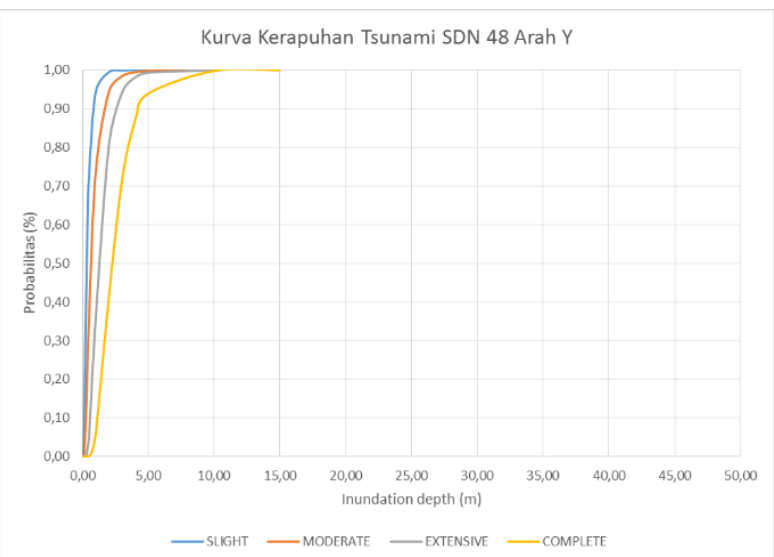

Fig. 9. Fragility Curve of SDN 48 Banda Aceh y-direction

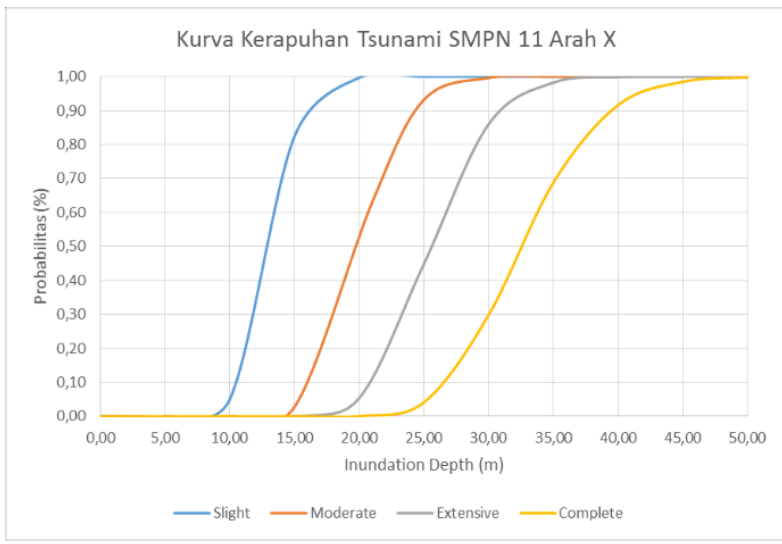

Fig. 10. Fragility Curve of SMPN 11 Banda Aceh x-direction

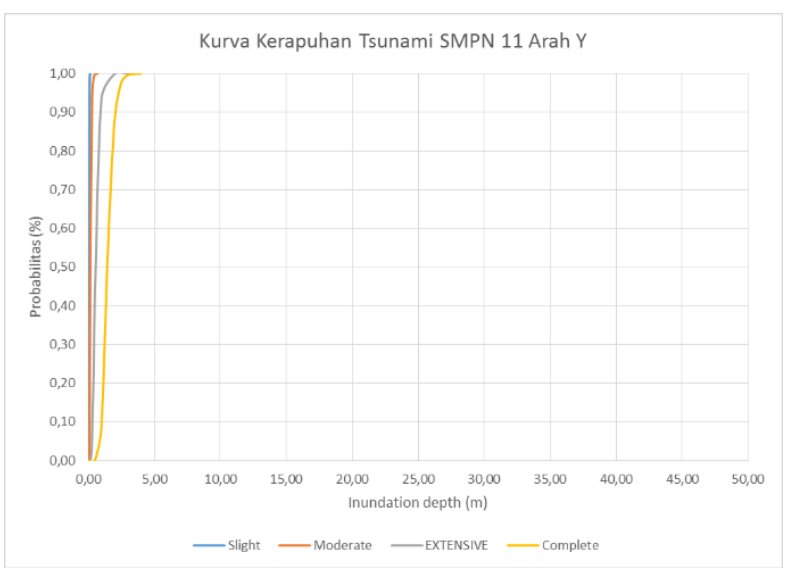

Fig. 11. Fragility Curve of SMPN 11 Banda Aceh y-direction 


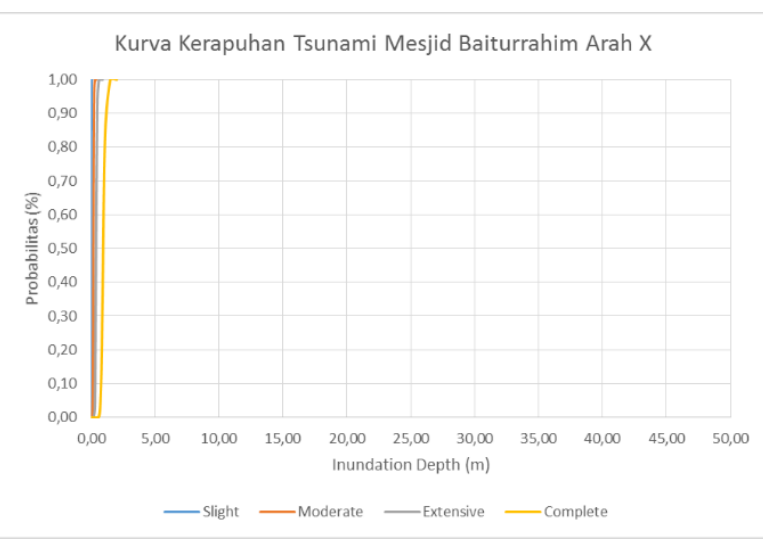

Fig. 12. Fragility Curve of Ulee Lheu Mosque x-direction

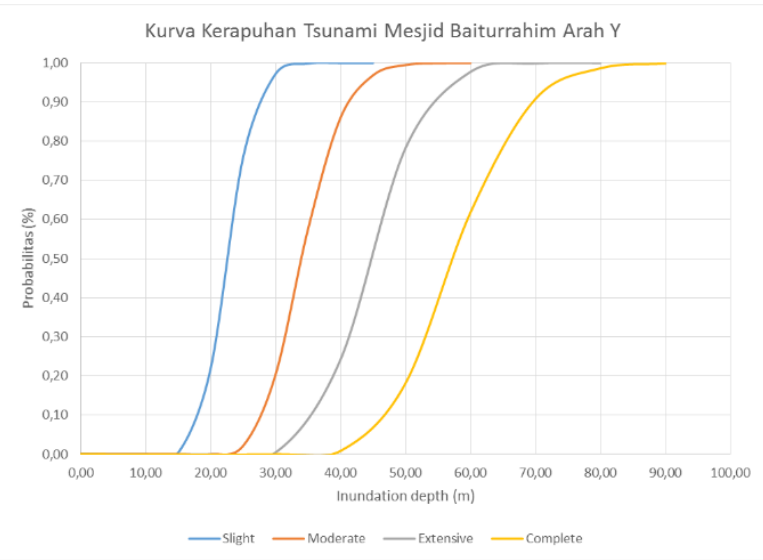

Fig. 13. Fragility Curve of Ulee Lheu Mosque y-direction

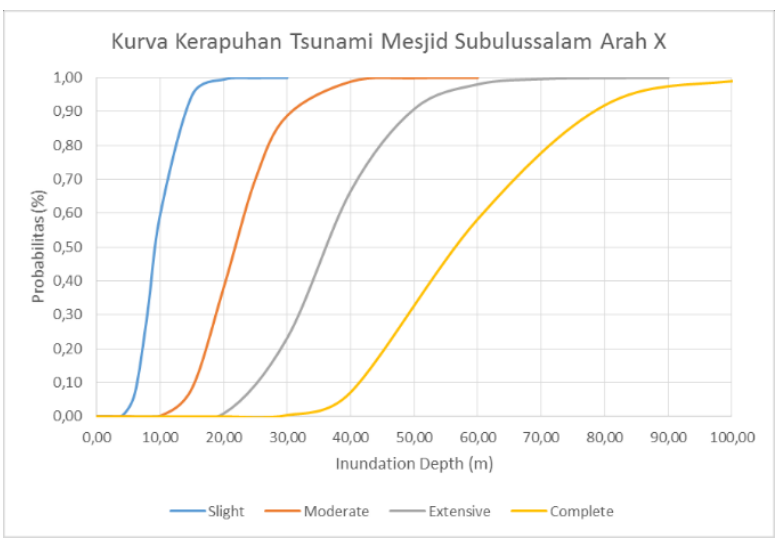

Fig. 14. Fragility Curve of Punge Mosque x-direction

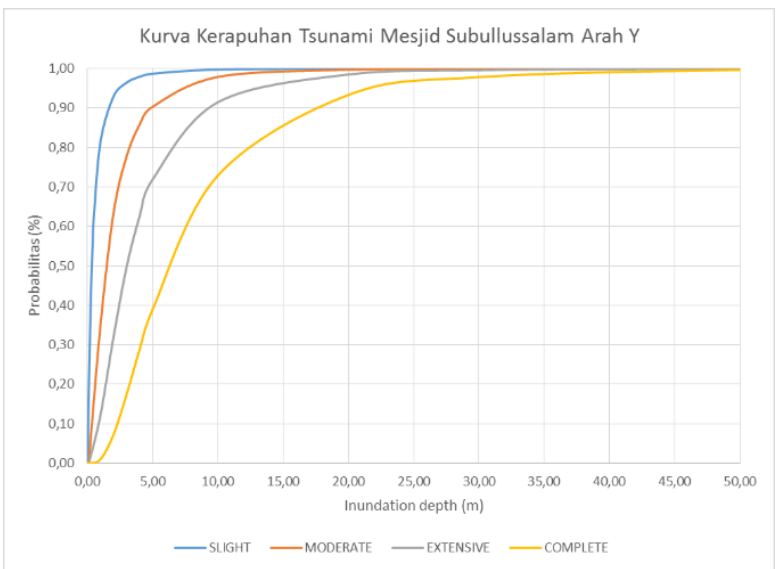

Fig. 15. Fragility Curve of Punge Mosque y-direction

Based on the fragility curve formed, the building structure has a $100 \%$ probability of damage which can be seen in Table 16 .

Table 16. Fragility curves for each building

\begin{tabular}{|c|c|c|c|c|c|}
\hline \multirow[b]{2}{*}{$\begin{array}{l}\text { Existing } \\
\text { Building }\end{array}$} & \multirow[b]{2}{*}{$\begin{array}{l}\text { Tsunami } \\
\text { Direction }\end{array}$} & \multicolumn{4}{|c|}{ Inundation Depth (m) } \\
\hline & & $\begin{array}{c}\text { Slight } \\
\text { Damage } \\
(100 \%)\end{array}$ & $\begin{array}{l}\text { Moderate } \\
\text { Damage } \\
(100 \%)\end{array}$ & $\begin{array}{l}\text { Extensive } \\
\text { Damage } \\
(100 \%)\end{array}$ & $\begin{array}{l}\text { Complete } \\
\text { Damage } \\
(100 \%)\end{array}$ \\
\hline \multirow{2}{*}{ TVE Lambung } & $\mathrm{x}$ & 30 & 50 & 60 & 80 \\
\hline & $\mathrm{y}$ & 30 & 60 & 70 & 100 \\
\hline \multirow{2}{*}{ TVE Alu Deah Teungoh } & $\mathrm{x}$ & 35 & 60 & 80 & 100 \\
\hline & $\mathrm{y}$ & 30 & 30 & 33 & 45 \\
\hline \multirow{2}{*}{ TVE TDMRC } & $\mathrm{x}$ & 23 & 37 & 43 & 57 \\
\hline & $\mathrm{y}$ & 10 & 12 & 15 & 24 \\
\hline \multirow{2}{*}{ SDN 48 Banda Aceh } & $\mathrm{x}$ & 15 & 17 & 22 & 33 \\
\hline & $\mathrm{y}$ & 2 & 5 & 7 & 10 \\
\hline \multirow{2}{*}{ SMPN 11 Banda Aceh } & $\mathrm{x}$ & 20 & 30 & 36 & 47 \\
\hline & $\mathrm{y}$ & 0,1 & 0,5 & 2 & 3 \\
\hline \multirow{2}{*}{$\begin{array}{l}\text { Baiturrahim Ulee Lheu } \\
\text { Mosque }\end{array}$} & $\mathrm{x}$ & 0,1 & 0,5 & 1 & 2 \\
\hline & $\mathrm{y}$ & 32 & 50 & 64 & 85 \\
\hline \multirow{2}{*}{$\begin{array}{l}\text { Subulussalam Punge } \\
\text { Mosque }\end{array}$} & $\mathrm{x}$ & 20 & 40,5 & 70 & 100 \\
\hline & $\mathrm{y}$ & 10 & 20 & 25 & 45 \\
\hline
\end{tabular}




\section{Conclusion}

The results of the damage probability analysis based on the fragility curve can be used to predict the level of damage to buildings in Meuraxa District with reinforced concrete structures due to tsunami in the future.

Acknowledgement. This research was conducted independently without external funding. The authors are grateful to Amirah Fasya for the assistance provided in the experimental work.

\section{References}

1. Jamie W. Mc Caughey et. all. (2017), Trust and distrust of tsunami vertical evacuation buildings: Extending protection motivation theory to examine choices under social influence, International Journal of Disaster Risk Reduction 24.

2. Roshan, A.D. et.all (2016) "Tsunami Hazard Assessment of Indian Coast" Natural Hazards 82(2) DOI: 10.1007/s11069-016-2216-1.

3. Delfebriyadi, 2010, "Rekayasa Gempa Teknik Sipil", CV. Ferila., Padang.

4. Goto, Y. et.all (2012), "Tsunami evacuation simulation for disaster education and city planning" Paper: Dr7-1-5086; 2012/1/24.

5. Federal Emergency Management Agency. 2012. Guidelines for Design of Structures for Vertical Evacuation from Tsunami Second Edition. Department of Homeland Security FEMA Mitigation Division: Washington D.C.

6. Karafagka, S., Fotopoulou, S., and Pitilakis, K. 2018. "Analytical tsunami fragility curves for seaport RC buildings and steel light frame warehouses", Soil Dynamics and Earthquake Engineering. 112 (2018): 118-137.

7. Medina, S. et. all. "Tsunami analytical fragility curves for the Colombian Pacific coast: A reinforced concrete building example", Engineering Structures. 196 (2019) 109309.

8. Federal Emergency Management Agency, 2004, Direct physical damage-general building stock, HAZUS-MH Technical manual, Chapter 5, Washington D.C. 